\title{
Possible cataractogenic effect of radionuclides deposited within the eye from the blood stream
}

\author{
T P GRIFFITH, ANTOINETTE PIRIE, AND JANET VAUGHAN \\ From the Department of Ophthalmology, W Cumberland Hospital, Nuffield Laboratory of Ophthalmology, \\ Oxford and Bone Research Laboratory, Nuffield Orthopaedic Centre, Oxford
}

SUMmaRY The clinical and histological examination of a cataract in a man of 47 is described together with a review of the deposition of radionuclides in the eye. It is suggested that the cataract was possibly due, at least in part, to irradiation of the sensitive cells in the germinative zone of the lens epithelium by alpha particles deposited in the pigmented tissues of the eye from the ${ }^{239} \mathrm{Pu}$ circulating in the blood.

It has long been recognised that exposure to external ionising radiation may result in a posterior polar cataract in rats, ${ }^{1}$ rabbits, ${ }^{2}$ and man, ${ }^{3}$ the primary injury being to the cells in the germinative zone of the lens epithelium. This is a single layer of cells under the capsule on the anterior face of the lens only. The cells of the germinative zone continue to divide throughout life (at an ever decreasing rate), and the daughter cells gradually differentiate into lens fibres which make up the body of the lens.

Ionising radiation permanently damages the cell nucleus in such a way that the products of cell division are abnormal and do not form normal lens fibres. The cell debris and abnormal fibres, resulting from division of the irradiated cells, gradually move from the equator to the posterior pole of the lens, where they form a disorganised plaque of material opaque to light. The higher rate of cell division in the young lens correlates with its greater sensitivity to radiation. ${ }^{45}$ Some of the peculiarities of radiation cataract arise from the fact that new lens fibres are laid down throughout life by slow proliferation of epithelium, so that, since no phagocytic system exists (the lens is enclosed in a capsule which is impermeable to cells), a damaged epithelial cell contributes permanent damage to the lens in the form of a damaged fibre. With the continuous growth with age, the damaged cells and fibres get 'pushed' under the capsule to the posterior pole of the lens and form a posterior polar cataract. Further opacities may later develop throughout the lens, and the condition then cannot clinically be distinguished from a senile cataract.

Correspondence to Mrs A Pirie, Nuffield Laboratory of Ophthalmology, Walton Street, Oxford OX2 6EW.
Little consideration, however, has been given to the possible cataractogenic effects of radionuclides deposited within the eye from the blood stream, though it is known that such deposition may occur. Stover et al. ${ }^{6}$ reported that there was prolonged retention of ${ }^{239} \mathrm{Pu}$, an alpha particle emitter, in the eyes of beagles after intravenous injection. Four years after the injection the concentration in the eye as a whole was a little over 10 times that in serum. When the ${ }^{239} \mathrm{Pu}$ was estimated in the separate parts of the eyes of dogs it could not be detected in cornea, lens, or vitreous body but was highest in iris and choroid, the pigmented parts. ${ }^{7}$ The eyes of dogs cannot, however, be directly compared to the human eye since part of the choroid is replaced by a tapetum lucidum-a structure not found in man.

Non-radioactive barium and strontium are normally present in the choroid and iris of cattle, pigmented rabbits, and, in lower concentrations, in man. ${ }^{8226} \mathrm{Ra},{ }^{228} \mathrm{Th}$, and ${ }^{210} \mathrm{Po}$ have been found in the choroid and iris of cattle. The concentration of ${ }^{226} \mathrm{Ra}$ noted was comparable with that in bone. ${ }^{9}$ Radioactive strontium, ${ }^{91} \mathrm{Sr}$, also concentrated in iris, ciliary body, and choroid of the pigmented rabbit eye, and there was only a slow release from these tissues. ${ }^{100}{ }^{\circ} \mathrm{Y}$, on the other hand, a decay product of ${ }^{\text {N}} \mathrm{Sr}$, was not found to be concentrated in pigmented areas of the rabbit's eye like "Nr but in the retina.

Further, Holtzman and Sha " measured the radium and calcium content in the eyes of two persons with a known high body burden of ${ }^{226} \mathrm{RA}$. They found the greatest concentration of ${ }^{226} \mathrm{Ra}$ was in the sclera, iris, and choroid and similarities between the $\mathrm{Ra} / \mathrm{Ca}$ ratio in the human choroid and that in bone (whole body). 
They suggest this may indicate that the dose rate to the choroid may be similar to that of bone. This is clearly wrong. The calcium concentration in the bone is very much larger than in the choroid, so that, with the radium and calcium ratio the same, the concentration of radium in the bone and therefore the dose is much larger in bone than in the choroid.

The importance of this uneven distribution of radionuclides within the eye, as far as cataractogenesis is concerned, is that the iris and ciliary body lie adjacent to that area of the lens epithelium in which the radiosensitive cells, capable of division, are situated. These cells are the forerunners of the lens fibres, but after irradiation the daughter cells degenerate before fibre formation begins, and it is these degenerate cells and ill-formed fibres that are the histological counterpart of the radiation cataract at the posterior pole of the lens.

We report here the appearance of a cataract removed from the eye of a relatively young man of 47 , which, we suggest, may have been caused, at least in part, by internal radiation from radionuclides deposited in the pigmented tissues of the eye.

\section{Case report}

$\mathrm{Mr} \mathrm{A}$ at the age of 23 started work in June 1950 at an establishment where he might be exposed to ionising radiation. In 1971 it was recorded that his vision was becoming impaired, but he worked there until October 1974, when he was withdrawn on account of his poor eyesight. He was at first an $x$-ray operator, a post which he held (and in which he would be subject to $x$-ray photon irradiation) for about a year until 1951 , when he became a process worker in the technical department until 1974. During this period he was potentially subject to all the radiation hazards associated with the type of work involved, namely, plutonium ingestion, external exposure to beta and gamma rays and fast neutrons, and inhalation of plutonium and other alpha and beta emitting radionuclides.

Up to 1970 the practice of the establishment was to assume that eye doses were the same as the whole body doses, which were measured by a film badge worn at chest level. In 1971 lead-loaded rubber aprons were introduced to provide extra whole body protection in certain work where it was not possible to provide adequate shielding in the 'glove boxes.' The chest level film badge was worn under the apron to record the whole body dose, and it was thought that the eye dose could be assessed by multiplying the whole dose by a calculated factor. Measurements, however, showed that this approach was not satisfactory (it overestimated the eye dose, and the factor differed with type and place of work). Therefore late
Table 1 Mr A: Occupational radiation doses

\begin{tabular}{|c|c|c|c|c|}
\hline $\begin{array}{l}\text { Time period, } \\
\text { years }\end{array}$ & Duration & $\begin{array}{l}\text { Whole body } \\
\text { dose, rems }\end{array}$ & $\begin{array}{l}\text { Neutron } \\
\text { dose, }{ }^{*} \text { rems }\end{array}$ & $\begin{array}{l}\text { Eye lens } \\
\text { dose, rems* }\end{array}$ \\
\hline $1950-59$ & 10 & $18 \cdot 40$ & - & $18 \cdot 40$ \\
\hline $1960-70$ & 11 & $36 \cdot 50$ & $(0 \cdot 73)$ & $36 \cdot 52$ \\
\hline $1971-74$ & 4 & $11 \cdot 61$ & 0.45 & $\begin{array}{l}15.09 \text { or } \\
31.99\end{array}$ \\
\hline Total & & 67 & & 70 or $87+$ \\
\hline
\end{tabular}

${ }^{*}$ Included in whole body dose.

†Depending on method of calculation.

in 1973 workers were issued with 'cap badges' to be worn at forehead level, from which to infer eye doses. Some details of his radiation dose are shown in Table 1.

The total whole body dose received by $\mathrm{Mr} \mathrm{A}$ was 67 rems (an overall average dose of $2 \cdot 8$ rems per year, with values between 4 and 6 rems per year in the period 1967-71 inclusive. His total estimated eye dose was $70-87$ rem (annual rate $3-5$ rems). It is impossible to calculate his exact cataractogenic dose. The first reports of cataracts in bomb survivors who had received a single large dose of external radiation were made in 1949, about four years after the explosion of the bombs on Japan. ${ }^{12}$

Between 1970 and $1974 \mathrm{Mr}$ A was involved in three known incidents involving contamination of his face with plutonium. In four other incidents his hands or his hands and face were recorded as exposed to alpha irradiation. In all cases the contamination was reported as small and removed within 24 hours by

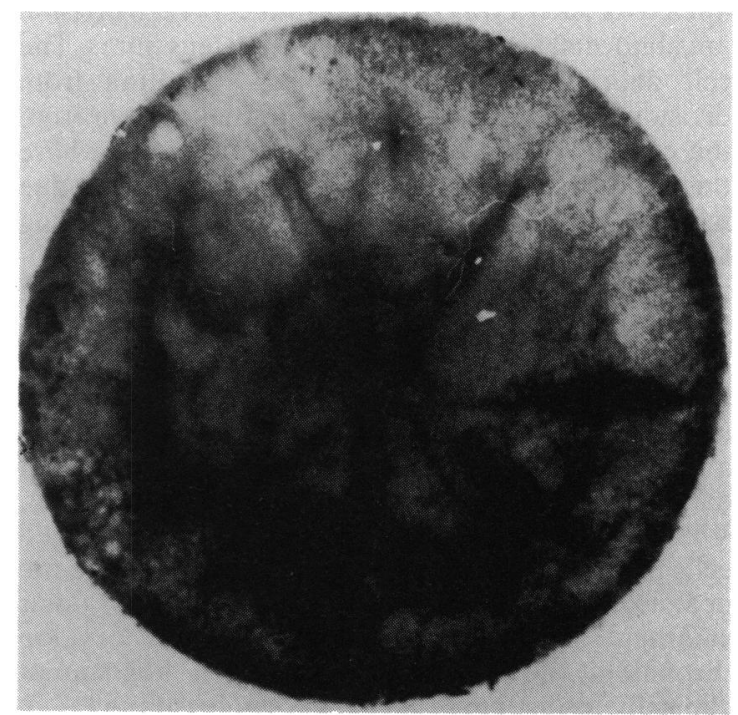

Fig. 1 Posterior surface of left lens, showing central opacity. $(\times 10)$. 


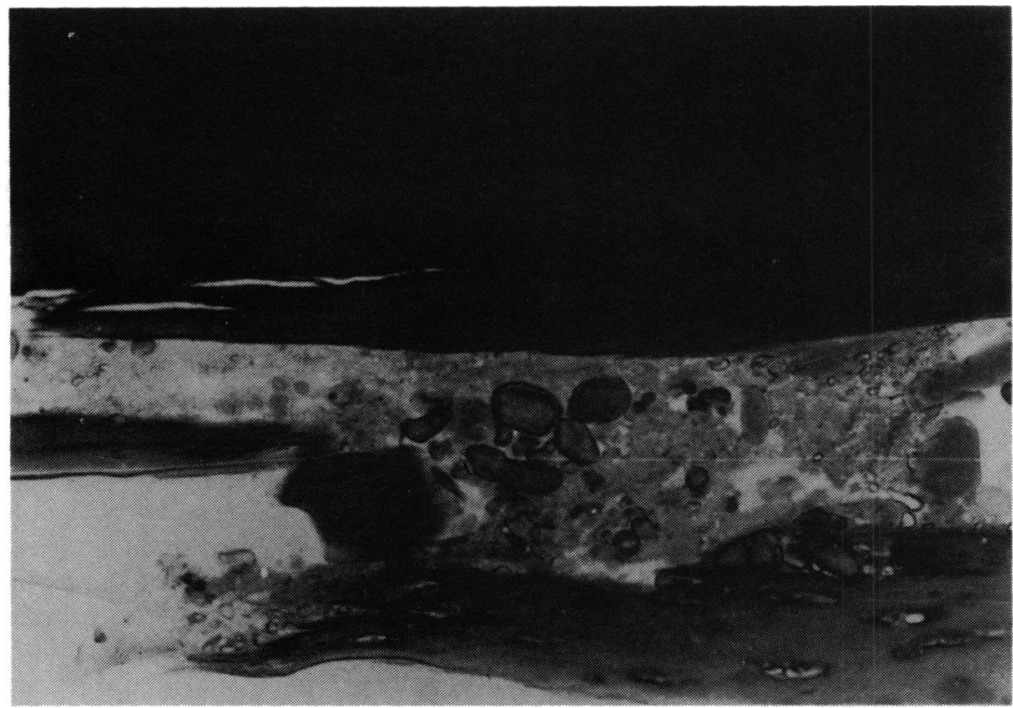

Fig. 2 Histological section of the posterior polar area of left lens. ( $H$ and $E, \times 230$ ).

simple procedures. From these incidents, and from his general work, some plutonium must, however, have reached the blood stream, since in 1974 the best estimate of his current plutonium burden was $2 \mathrm{nCi}$, estimated from urinary excretion. It is recognised that such urinary excretion methods are far from satisfactory for a variety of reasons..$^{1314}$ They can give only an approximate indication of the body burden and in practice usually overestimate this. Measurement in the whole body monitor for ${ }^{239} \mathrm{Pu}$ in the lung was negative. He had never used a microwave oven at home and had not worked in a radar environment.

On account of his poor eyesight $\mathrm{Mr} \mathrm{A}$ was referred to one of us (TPG), who reported on 23 January 1975: 'The left eye shows some subcapsular lens opacities more marked in the region of the posterior pole; a polychromatic lustre was noted in one small area of these posterior pole opacities. There were also a few opacities near the anterior pole of the lens with the appearance also of one small vacuole. It is possible that Mr A's cataracts may have been due to radiation. The appearance at the moment is not quite typical although it is noted that there is no report of any family history of premature cataract in the family, it is also noted that $\mathrm{Mr} \mathrm{A}$ is relatively young to be normally expected to develop cataract.'

After removal of the left lens TPG reported on 20 September 1976: "the "sunflower" appearance of the cataract suggested that this was a complicated cataract with some toxic process being involved. I know of no specific evidence for the type of left lens opacity (or cataract) present being due to radiation.'

In 1977 a cancer (transitional cell type) of the pelvis of the left kidney was removed.

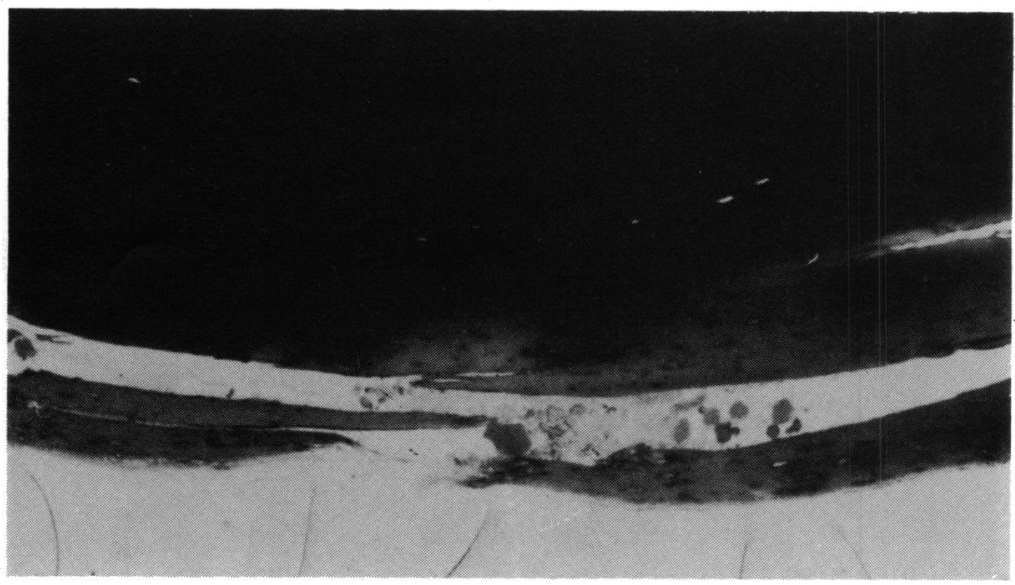

Fig. 3 Histological section of the posterior polar area of left lens. (Hand $E, \times 57)$. 


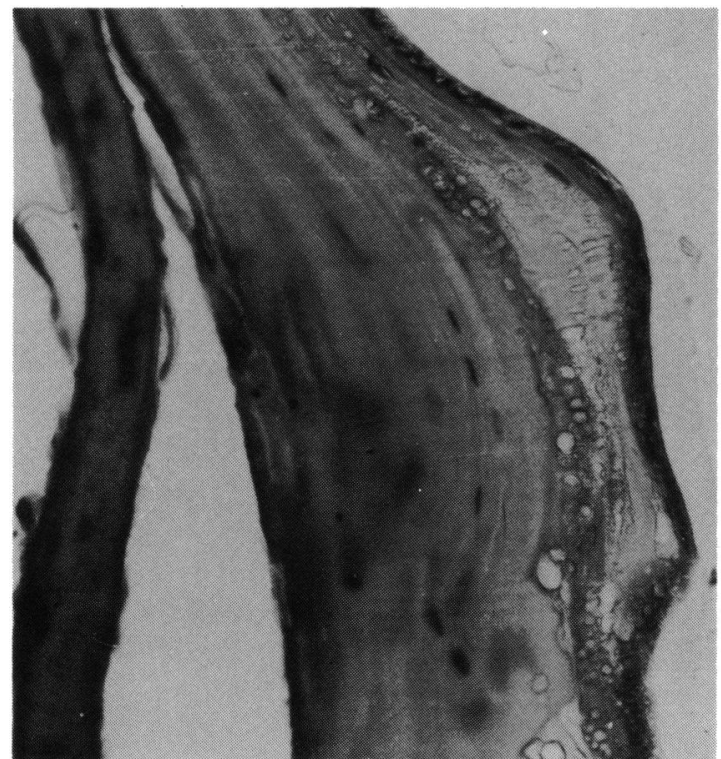

Fig. 4 Lens equator showing disorganised cortex. $(\times 210)$.

\section{HISTOLOGICAL EXAMINATION OF THE CATARACT}

Naked eye examination of the extracted lens, fixed in formalin, showed diffuse opacities in the anterior cortex and an opacity at the posterior pole of the lens just under the capsule, together with striate opacities radiating from this into the deeper posterior cortex of the lens Fig. 1. Sections of the lens were made and stained with haematoxylin and eosin. The human cataractous lens is a notoriously difficult material, being liable to fracture during sectioning. Mr A's lens was no exception, and the posterior capsule of the lens detached during the process. Fig. 2 is a photomicrograph of the posterior pole area of the lens taken at high magnification. Fig. 3 is a photomicrograph at a lower magnification which includes the same area as Fig. 2. Disorganisation of cortical lens fibres stretched from the posterior to the equator and anterior pole (Figs. 4 and 5). The deeper posterior cortex was also involved, giving rise to the striate opacities seen in the whole lens before sectioning (Fig. 1). Part of the disorganisation in the anterior cortex may have been due to trauma during cryoextraction of the lens at operation.

The epithelium, viewed in section, showed gaps between epithelial cells and in other places vacuoles or reduplication of the normal single layer of epithelium (Fig. 6); some cells had pyknotic nuclei (Fig. 7). The sections we have examined did not show any dividing cells, normal or abnormal, nor the spindle shaped cells described by Hayes and Fisher. ${ }^{15}$

\section{Discussion}

We have described the appearance during life and the subsequent histological examination of a cataract affecting primarily the posterior pole of the lens of a man of 47 , which had some of the characteristics of cataracts induced by external radiation. ${ }^{3} \mathrm{Mr}$ A's cataract started in the posterior polar region. This parallels the development of cataracts in the populations of Hiroshima and Nagasaki that have been accepted as due to external radiation. ${ }^{16}$ Extraction of a posterior polar cataract, or of a senile cataract, is extremely rare below the age of $50 .{ }^{17}$ Studies in an Oxfordshire population of 17695 men aged 40-49 yr over a six-year period found only seven posterior
Fig. 5. Anterior polar area of lens: cortical fibres disorganised and epithelium detached.

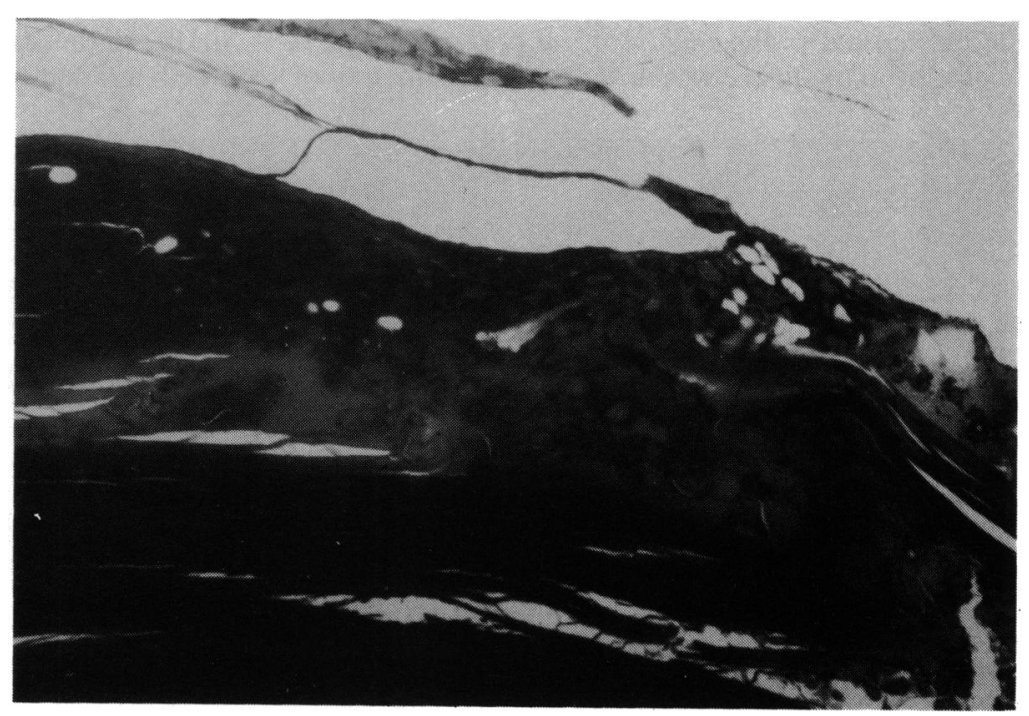




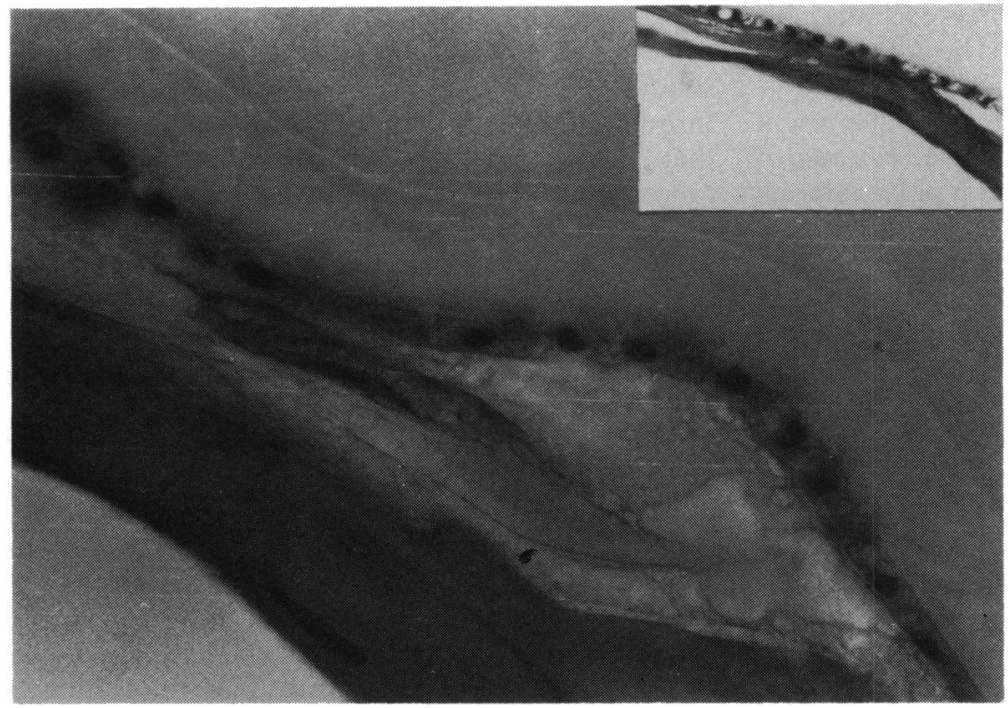

Fig. 6 Disorganised cortex adjacent to anterior pole showing abnormal epithelium.

polar subcapsular cataracts, and three senile cataracts needed extraction during that time-that is, $0 \cdot 66 / 10000 / \mathrm{yr}$ of posterior polar subcapsular and $0 \cdot 28 / 10000 / y r$ of senile cataracts.

Hayes and Fisher ${ }^{15}$ have described posterior polar cataracts extracted from a man who had been exposed for 11 y to low dosage $x$ rays. The lenses were removed $26 \mathrm{yr}$ later at the age of $65 \mathrm{yr}$ (personal communication). In most respects the histological and clinical appearance of this lens corresponded with that of $\mathrm{Mr} \mathrm{A}$, though feathery fibres were not noted in $\mathrm{Mr} \mathrm{A}$ 's lens, perhaps due to differences in fixation and staining methods. Extraction of Mr A's lens was needed a year and nine months after the posterior polar opacity was first seen clinically, and by that time further changes had taken place, as they had in the lens described by Hayes and Fisher. ${ }^{15}$

A posterior polar subcapsular cataract may occur with the more common features of senile cataract in older age groups. In some patients there may be a recognised cause-for example, trauma or local ocular disease such as retinitis pigmentosa, gyrate atrophy, or uveitis. Other known causes are dystrophia myotonica, systemic steroids, radiation, anorexia nervosa, retinal detachment, absolute glaucoma, intraocular tumours, cyclitis, and iridocyclitis. It must also be recognised that it may be impossible to assign a known cause to a particular

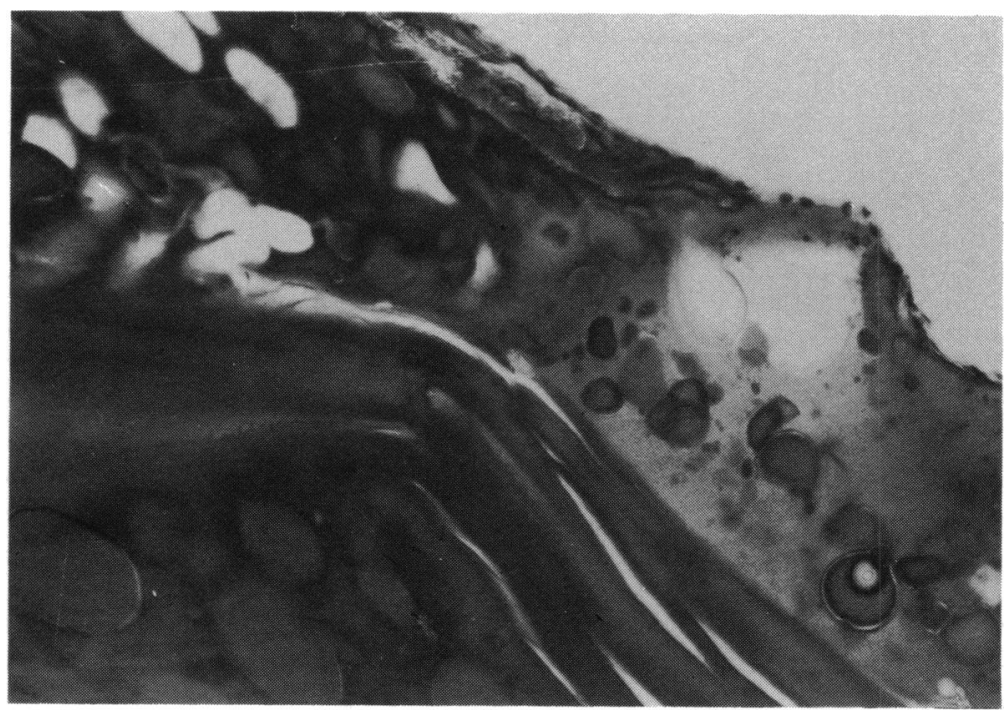

Fig. 7 Epithelium, showing gaps, vacuoles, and reduplication. $(\times 210)$. 
posterior polar cataract. If radiation is excluded, $\mathrm{Mr}$ A's cataract would be in this class, as he did not suffer from any of the above diseases.

In considering the possible aetiology of the present cataract it should be noted that it occurred in a man of 47 years. The extraction of a posterior polar cataract is extremely rare in a middle aged man. ${ }^{17}$ The classic senile cataract occurs in older age groups. In any other person than $\mathrm{Mr} \mathrm{A}$ the cataract would have been regarded as the unique cataract, originating at the posterior pole, to be found in a large population of the middle aged, but in view of his exposure to radiation the origin of his cataract at least merits discussion.

Mr A had been exposed to low levels of external irradiation but was also known to have a small body burden of ${ }^{239} \mathrm{Pu}$. It is possible therefore that the sensitive cells of the lens may have been irriadiated also by alpha rays from plutonium deposited from the blood stream in the pigmented epithelium of the iris and ciliary body, which are adjacent to the radiation sensitive cells in the germinative zone of the lens epithelium.

Basing their conclusions on available clinical evi- dence the International Commission on Radiological Protection ${ }^{18} 19$ have recommended that cataract should be regarded as a form of injury, with a dose threshold above 30 rem per year for a life time, and that the occupational dose limits for external radiation of the lens should be $0.3 \mathrm{~Sv}(30 \mathrm{rems})$ a year. Cataract is regarded by the ICRP as a 'nonstochastic' effect, that is, its severity varies with the dose, and a threshold dose is therefore to be expected. The latest dose, using the 'best' model in the statistical sense, for lenticular opacities among atom bomb survivors is $110-147$ rads for gamma rays. The question whether there is a threshold for neutrons remains uncertain. ${ }^{16}$

The total external radiation dose recorded as received by $\mathrm{Mr} \mathrm{A}$ over 24 years was equivalent to about two years' exposure at the dose limit for the eye and thus well below the threshold for the occurrence of external radiation-induced cataract. Again the small body burden of plutonium, $(2 \mathrm{nCi})$ as estimated from urine examination, was well below the occupational dose for the whole body. It is however known that ${ }^{239} \mathrm{Pu}$ retention in the human eye exceeds that in many other soft tissues. ${ }^{21}$ Autoradiographic studies

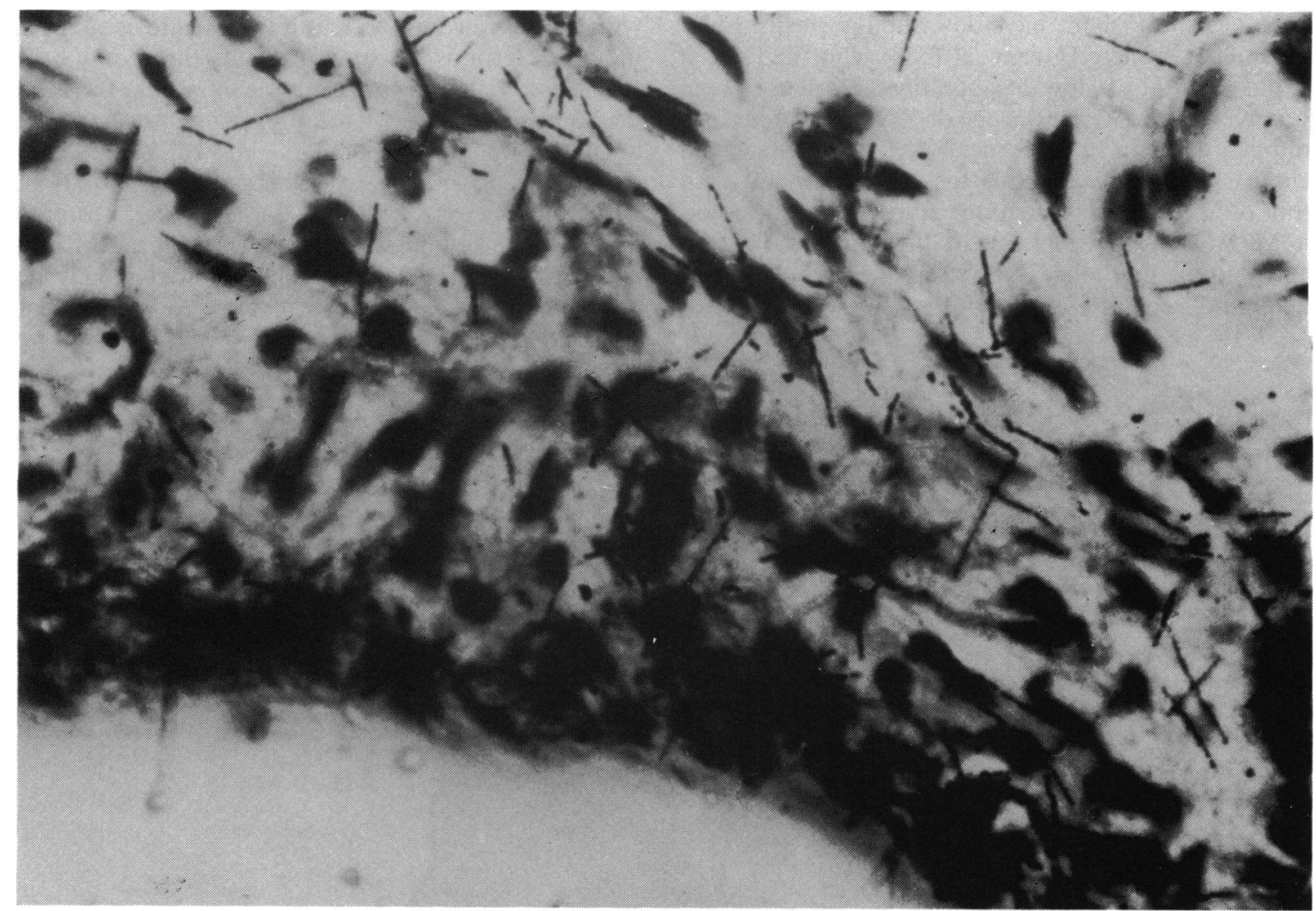

Fig. 8 Autoradiograph of iris of dog injected intravenously $(5 \mu \mathrm{g} / \mathrm{kg})$ plutonium citrate and killed $24 \mathrm{~h}$ later. Note alpha tracks. $(\times 2630)$. 


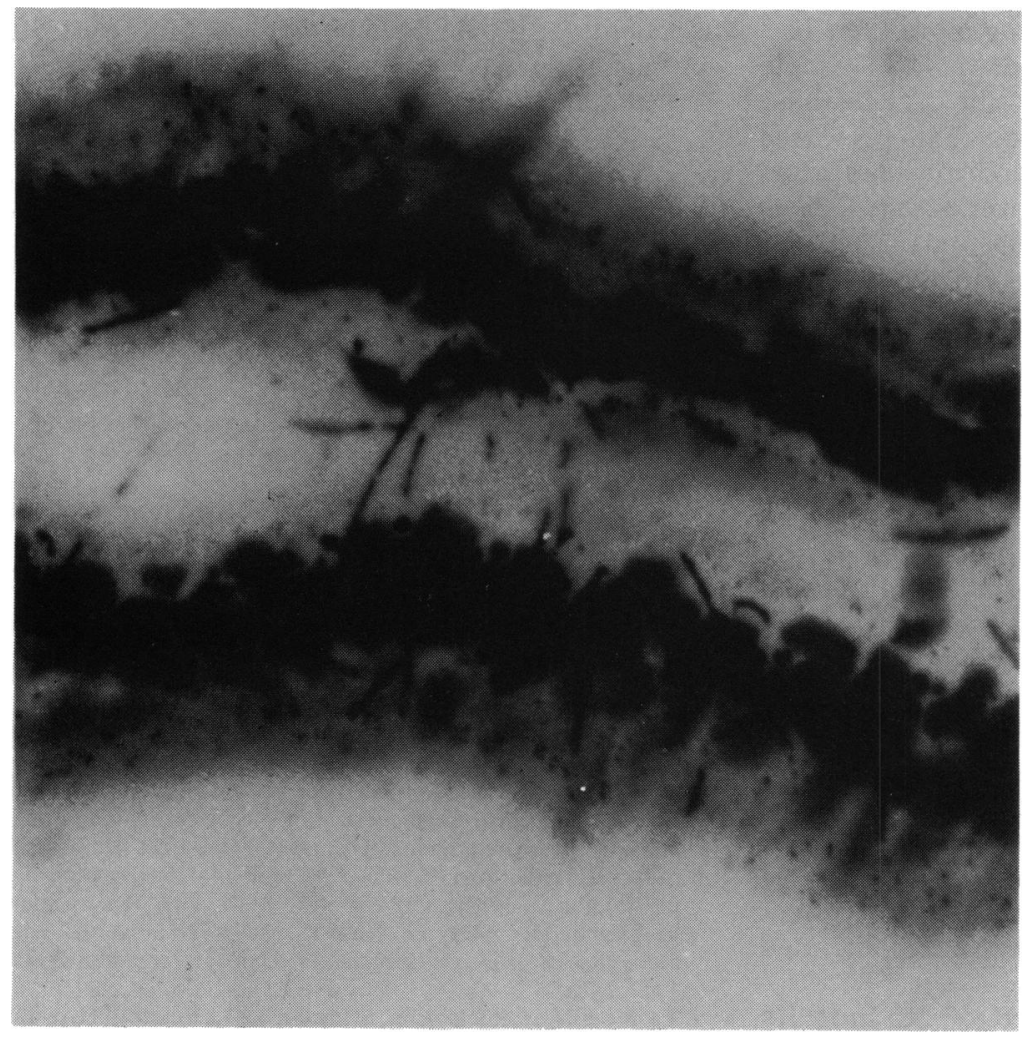

Fig. 9 Autoradiograph of ciliary process of dog injected intravenously $(5 \mu \mathrm{c} / \mathrm{kg})$ plutonium citrate and killed $24 \mathrm{~h}$ later. Note alpha tracks. $(\times 2718)$.

of ${ }^{239} \mathrm{Pu}$ distribution in the eye of the dog have shown that this retention in the eye occurs specifically in the iris and ciliary processes (Pirie A, Vaughan J, personal communication) as does that of other radionuclides already discussed. This is shown in Figs. 8 and 9. Some at least of the alpha radiation would be within reach of the radiation sensitive cells in the germinative zone of the lens epithelium, since the range of an alpha particle of plutonium is about $35 \mu \mathrm{m}$ in tissue ${ }^{21}$ and the distance between the iris and the sensitive cells lies within the same range. ${ }^{22}$ Such local irradiation by alpha particles would be expected to be more effective than external penetrating radiation, since alpha particles have a greater biological effect than either gamma rays or neutrons as recognised by the quality factor used in calculating absorbed dose for different types of radiation. The quality factor for alpha particles is 20 compared with 1 for gamma rays and 10 for neutrons. ${ }^{18}$ In an early series of observations on a small number of young rabbits Von Sallman and his colleagues found alpha particles to be more cataractogenic than $x$ rays or gamma radiation dose for dose. ${ }^{22}$

Although there are no reports of cataract due to ingested or inhaled plutonium in man or in experi- mental animals, there is some evidence that cataract is a possible hazard from the therapeutic use of, or industrial exposure to, radium isotopes.

A high incidence of cataract and conspicuous multiple naevi of the iris was first reported in a group of patients given therapeutic amounts of ${ }^{224} \mathrm{Ra}$ in childhood for the treatment of tuberculosis and ankylosing spondylitis. ${ }^{23}{ }^{224} \mathrm{Ra}$ decays rapidly to a series of radioactive daughter products which may irradiate soft tissues. ${ }^{24}$ It was first given as a mixture known as 'Peteosthor,' which contains platinum and eosin. ${ }^{23}{ }^{24}$ Recent experiments with mice have shown that the tissue distribution of ${ }^{224} \mathrm{Ra}$ was not affected by whether it was given pure or with platinum, but since no cataracts were reported in either set of mice it is not yet known whether platinum can cause cataracts. ${ }^{25}$ In the most recent follow-up of 218 juveniles (aged 1-20) and 680 adults (aged 35-47) who received repeated injections of ${ }^{224} \mathrm{Ra}$ about 30 years ago, some in the form of Peteosthor (Spiess $\mathrm{H}$, Mays CW, personal communication), 11 cataracts in juveniles and 25 in adults were found. The average age at which cataract was reported in the juveniles was 35 years, with a range of 14-46 years. ${ }^{24}$ The incidence of reported cataracts increased significantly 
with dosage. In juveniles receiving more than $14 \cdot 3$ $\mu \mathrm{Ci} / \mathrm{kg}{ }^{224} \mathrm{Ra}$ the cataract incidence was $11 / 154$, while no cataracts were seen among the 57 juveniles receiving lower amounts. In the adult patients whose dose exceeded $14 \cdot 3 \mu \mathrm{Ci} / \mathrm{kg}$ the cataract incidence was $17 / 245$ compared with $7 / 400$ at lower dosage (Spiess $\mathrm{H}$, Mays $\mathrm{CW}$, personal communication). The most recent report on a further group of 274 adults treated with much smaller doses of ${ }^{224} \mathrm{Ra}(280 \mu \mathrm{Ci})$ for ankylosing spondylitis notes seven cases of cataract. The mean time from initiation of treatment was 26 years and the mean age at diagnosis was 66 years. The authors consider that the cataract incidence was not unusual for the age group. ${ }^{26}$ The soft tissue dose is not known, but the skeletal dose was several 100 rads in the Spiess juvenile cases $^{24}$ compared with 14-125 rads in the adult cases discussed by Wick and Goessner. ${ }^{26}$ The character of the cataract is not known in any of the patients treated with ${ }^{224} \mathrm{Ra}$. However, the high incidence of cataracts in juveniles, some of them as young as 2 years when first treated (Spiess H, Mays CW, personal communication), suggests that the radionuclide ${ }^{224} \mathrm{Ra}$ (or the eosin or platinum) may be cataractogenic, particularly in an age group when the lens is most radiosensitive and high doses are given. The sensitivity of the lens in young animals has been well demonstrated experimentally. ${ }^{4}$

Many women have been exposed to ${ }^{226} \mathrm{Ra}$ and ${ }^{22 k} \mathrm{Ra}$ through their work as painters of the luminous dials of watches. Löscher ${ }^{27}$ reported bilateral posterior subcapsular cataracts in a 56-year-old woman who had worked for 25 years painting luminous radium dials and concluded that these were due to her occupational exposure to radium, which would have included external exposure to gamma rays. ${ }^{28}$ More recently Adams et al. ${ }^{28}$ have surveyed 813 women who were exposed as dial painters before 1930 at a mean age of about 19 years. There were 119 cataracts of unspecified type. The time between first exposure and diagnosis of cataract was less in those whose calculated radium intake to the blood was greater than $50 \mu \mathrm{Ci}$ (140 women) than in those whose intake was lower than this (673 women). The authors conclude that more work is needed before deciding whether or not the cataracts were due to radiation. Though they suggest that duration of employment may be used as an index of the possible participation of external radiation sources in the working environment, they do not discuss whether the radiation involved in cataract induction was alpha particle radiation from ${ }^{226} \mathrm{Ra}$ deposited in the pigmented tissues of the eye or gamma radiation from exposure to environmental sources as is proposed in the case of excess breast cancers in British luminisers. ${ }^{29}$

No excess of cataracts is reported in a large group of patients (approximately 3900) given thorotrast, ${ }^{311} \mathrm{a}$ contrast medium containing ${ }^{232} \mathrm{Th}$. The decay chain of ${ }^{232} \mathrm{Th}$ contains both ${ }^{226} \mathrm{Ra}$ and ${ }^{224} \mathrm{Ra}$.

We are grateful to Dr W J Meredith for estimates of the external radiation dose received by $\mathrm{Mr} \mathrm{A}$ and to $\mathrm{Dr}$ Robin Mole and $\mathrm{Mr} \mathrm{A}$ Bron for helpful discussions. We thank Mrs Overall for making the autoradiographs and Mr Ian Robertson, Newcastle upon Tyne, for bringing this case to our attention.

\section{References}

1 Goldman NH, Liechti A. Experimentelle Untersuchungen über dic Genese der Rontgenstars. Albrecht von Graefes Arch Klin Ophthalmol 1938; 138: 722-36.

2 Poppe E. Experimental investigation of the effect of roentgen rays on the eye. General Department Norwegian Radium Hospital, Oslo: Kommisjon Hospital, Jacob Dybwad: 1942.

3 Cogan DG, Donaldson DD, Reese AB. Clinical and pathological characteristics of radiation cataract. Arch Ophthalmol 1952; 47: 55-70.

4 Cogan DG, Donaldson DD. Experimental radiation cataracts I. Cataracts in the rabbit following single $x$-ray exposure. Arch Ophthalmol 1951; 45: 508-22.

5 Von Sallmann L. Experimental studies on early lens changes after roentgen irradiation. III. Effect of $x$ radiation on mitotic activity and nuclear fragmentation of lens epithelium in normal and cysteine treated rabbits. Arch Ophthalmol 1952; 47: 305-20.

6 Stover BJ, Atherton DR, Mays CW. Studies of the retention and distribution of ${ }^{226} \mathrm{Ra},{ }^{239} \mathrm{Pu},{ }^{228} \mathrm{Ra},{ }^{228} \mathrm{Th}$, and ${ }^{90} \mathrm{Sz}$ in adult beagles. In: Dougherty TF, Jee WSS, Mays CW, Stover BJ, eds. Some aspects of internal irradiation. Oxford: Pergamon Press, 1962: 7-25.

7 Taylor GN, Rehfeld CE, Schneebeli G, Johnson HA. In: Dougherty TF, Jec WSS, Mays CW, Stover BJ, eds. Some aspects of internal irradiation. Oxford: Pergamon Press, 1962: $163-78$.

8 Sowden E, Piric A. Barium and strontium concentrations in eye tissuc. Biochem J 1958; 70: 716-7.

9 Hunt VR. Concentrations of ${ }^{210} \mathrm{Po}{ }^{226} \mathrm{Ra}$ and ${ }^{228} \mathrm{Th}$ in the choroid of the eye, particularly in cattle. In: Åberg S, Hungate FP, eds. Radioecological concentration processes. Oxford: Pergamon Press, 1967: 303-11.

10 Mole RH, Pirie A, Vaughan JM. Differential distribution of radioactive strontium and $y$ trium in the tissues of the rabbit's eye. Nature 1959; 183: 802-7.

11 Holtzman RB, Sha JY. ${ }^{226} \mathrm{Ra}$ and calcium in the human eye. Argonne National Laboratory Radiological and Environmental Research Division. Annual Report July 1976-June 1977. ANL 77-65, part 2: 72-6.

12 Dodo T. Review of thirty years study of Hiroshima and Nagasaki atomic bomb survivors' cataracts. J Radiat Res (Tokyo) 1975; 16 (suppl): 132-7.

13 Vaughan J, Blcanley B, Taylor DM. The distribution, excretion and the effects of plutonium as a bone seeker. In: Hodge HC, Stannard JN, Hirsch JB, eds. Handbook of experimental Pharmacology. New York: Springer, 1973: 349-502.

14 Rundo J, Holtzman RB. In: Jee WSS, ed. The health effects of plutonium and radium. Utah: JW Press, 1976: 497-504.

15 Hayes BP, Fisher RF. Influence of a prolonged period of lowdosage $x$-rays on the optic and ultrastructure appearances of cataract of the human lens. Br J Ophthalmol 1979; 63: 457-64.

16 Otake M, Schull WJ. The relationship of gamma or neutron radiation to posterior lenticular opacities among atomic bomb survivors in Hiroshima and Nagasaki. Radiat Res 1982; 92: 574-95.

17 Caird FI, Hutchinson M, Pirie A. Cataract in an English population. BrJ Prev Soc Med 1965; 19: 80-4. 
18 International Commission on Radiation Protection. Recommendations of the International Commission on Radiological Protection. ICRP Publications 26. Ann ICRP 1977; 1: 1-43.

19 International Commission on Radiation Protection. Statement and recommendations of the International Commission on Radiological Protection from its 1980 meeting. Ann ICRP 1980; 4: $1-5$.

20 Larsen RP, Oldham RO, Cacic CC, Farnham JE, Schneider JR. In: Rowland RE, Stehney AF, eds. Radiological and Environmental Research Division Annual Report. Part 2. Centre for Human Radiobiology, Argonne National Laboratory, Argonne, Illinois, 1979: 145-53.

21 Spiers FW. Radioisotopes in the human body, physical and biological aspects. Am Inst Biol Sci Monogr Ser Radiat Biol. New York: 1968.

22 Von Sallman L, Tobias CA, Auger HO, et al. Effects of highenergy particles, $x$-rays and aging on lens epithelium. Arch Ophthalmol 1955; 54: 489-514.

23 Spiess H. ${ }^{224} \mathrm{Ra}$ induced tumours in children and adults. In: Mays
CW, Jee WS, Lloyd RD, Stover BJ, Dougherty JH, Taylor GN, eds. Delayed effects of bone-seeking radionuclides. Salt Lake City: University of Utah Press, 1969.

24 Spiess H, Gerspach A, Mays CW. Soft tissue effects following ${ }^{224} \mathrm{Ra}$ injections into humans. Health Phys 1978; 35: 61-81.

25 Wick RR, Muller WA, Linzner U. Distribution studies in mice of ${ }^{224} \mathrm{Ra}$ in colloidal (Peteosthor) and ionic preparations as used in human therapy. Health Phys 1983; 44 (suppl 1): 580-3.

26 Wick RR, Gössner W. Follow-up study of late effects in ${ }^{224}$ Ra treated ankylosing spondylitis patients. Health Phys 1983; 44 (suppl 1): 187-95.

27 Löscher C. Cataract in radium dial painter. Klin Monatsbl Augenheilkd 1963; 142: 743-7.

28 Adams EA, Brues AB, Anast GA. Survey of ocular cataracts in radium dial workers. Health Phys 1983; 44 (suppl 1): 73-9.

29 Baverstock KF, Papworth GD, Vennart J. Risks of radiation at low dose rates. Lancet 1981; i: 430-3.

30 Mole RH. The radiobiological significance of the studies with ${ }^{224} \mathrm{Ra}$ and thorotrast. Health Phys 1978; 35: 167-74. 